\title{
Assessment of Influence of External Factors on Financial Stability of Construction Companies
}

\author{
MariaVlasenko \\ Senior lector, Department of Audit, Accounting and Finance \\ ORCID \\ E-mail:vma-1991@yandex.ru \\ Novosibirsk State Technical University, Novosibirsk, Russia
}

Journal of Corporate Finance Research, Vol. 14, No. 3, pp. 51-62 (2020)

DOI: https://doi.org/10.17323/j.jcfr.2073-0438.14.3.2020.51-62

Received 13 April 2020 | Peer-reviewed 15 May 2020 | Accepted 25 May 2020 


\section{Assessment of Influence of External Factors on Financial Stability of Construction Companies}

\section{Abstract}

When Russian construction companies switch to project financing they face a number of problems which have a negative impact on their operations. While a company is able to influence internal factors (such as resources, capital, their utilization efficiency etc.) it is virtually impossible to control external factors (inflation, unemployment, government policy etc.). These factors make a company less stable financially. One of manifestations of financial stability is resistance to external environmental disturbances. External factors influence corporate financial stability, they are mortgage rate, price increase index etc. Defining the extent of influence of external factors will help to mitigate the impact of external environment, alleviate the consequences. This makes the topic of the research relevant and increases the significance of analysis of external factors which influence corporate operations.

In this paper we conducted content analysis of the financial stability definition; evaluated financial stability of 50 construction companies of the Siberian Federal District; selected statistical information by constituent entities of the Siberian Federal District which influences construction companies' operations; assessed influence of the selected factors on financial stability of construction companies applying the binary choice model (logit model). The research showed that mortgage rate, consumer price index and nominal average salary influence construction companies of the Siberian Federal District. If influence of these factors is taken into consideration when planning and managing construction companies' resources they will be able to resist the impact of external environment and improve their financial stability.

Key words: financial stability, logit model, regression analysis, mortgage rate, average salary, consumer price index, construction companies of the Siberian Federal District

JEL classification: G30, C81, M21 


\section{Introduction}

When Russian construction companies switch to project financing they face a number of problems which have a negative impact on their operations. This happens because when a co-investment agreement is concluded a commercial bank acts as an intermediary, it holds the co-investors' funds and finances construction of a residential building from loan funds, thus increasing the construction project value and resulting in credit risks. While a company is able to influence internal factors (such as resources, capital, their utilization efficiency etc.) it is virtually impossible to control external factors (inflation, unemployment, government policy etc.). These factors make a company less stable financially.

Financial stability is a controversial notion. Studying this definition it should be noted that Russian scientists interpret it in a narrow and wide sense. In the narrow sense financial stability is maintenance of the target capital structure [1] which manifests itself in liquidity and solvency [2], [3]. In the wide sense financial stability constitutes ensuring of attainment of financial goals accompanied by response to disturbance of external and internal environment [4]. Foreign researchers adhere to the widesense interpretation [5], [6]. A great number of definitions offered by various authors makes it difficult to interpret this notion explicitly enough. It is necessary to provide an exact definition to financial stability when studying it. So a rather complete definition was offered by [4]: in the financial stability management a large set of tooling is used which comprises practices of correlation and regression analysis, strategic management etc.; a greater number of factors is defined which influence financial stability (including the external environment factors). This makes it possible to identify rational management solutions.

One of manifestations of financial stability is resistance to external environmental disturbances. External factors influence corporate financial stability, they are mortgage rate, price increase index etc. So we determine the research objective which consists in defining of influence of external factors on corporate financial stability. In this paper we conduct content analysis of financial stability definition and evaluate influence of factors on financial stability of certain industries in various countries. We consider application of the binary choice model (logit model) when assessing influence of external factors on financial stability of construction companies.

We discuss in this paper extension of the financial stability notion, review the construction industry, assess influence of external factors on financial stability of construction companies of the Siberian Federal District.

\section{Approaches to Interpretation of the Financial Stability Definition}

In contemporary literature financial stability is considered not just as a line of financial analysis but also as a separate scope of research because in a turbulent environment a company should ensure a sustainable growth of the business value when managing financial stability. Therein the system of financial stability management is considered as the most important component of the complex mechanism of maintaining the corporate financial soundness [4]. So, financial stability management means balancing resources (assets and liabilities) in such a way which provides capital expansion and improvement of corporate good standing.

In order to manage financial stability it is necessary to understand its essence. For all the variety of concept definitions it is difficult to choose the definition which describes completely the essence of financial stability. Russian scientists offer concept definitions of financial stability in a narrow and wide sense. Financial stability in the narrow sense implies corporate internal resources, that is capital, which, in our opinion, is unacceptable in the current economy. In the wide sense financial stability means a stable corporate operation which takes into consideration the state of internal resources and external environment.

V.V.Kovalev thinks that financial stability is the company's capability to maintain the target structure of funding sources over the long term [1]. The author of this definition limits financial stability to capital structure failing to take into account the fact that maintaining the target capital structure may result in deterioration in performance, loss of profit, hence, capital. It follows that there is no point in considering financial stability only from the point of view of the funding sources' structure.

Corporate financial stability rests on the optimum ratio of resources to their sources taking into consideration capital structure, degree of corporate liquidity and solvency. This is confirmed in papers by M.V. Mel'nik [2], G.V. Savitskaya [3], E.Yu. Fayantzeva [7]. This approach to interpretation of financial stability describes it to a greater extent. In other words capital structure is considered as a display of financial stability interrelated with solvency and liquidity. Consequently, a company may be financially stable if it provides the optimal capital structure and settles liabilities in due time.

Vladimirova T.A. and Sokolova T.V. [4] presume that financial stability of a company may be understood as its capability to achieve its financial goals responding promptly to change of internal and external environment, thus, mitigating their disturbing influence. This definition expresses the essence of financial stability most broadly. It is due to the fact that financial stability manifests itself in the balance between resources' and capital's utilization efficiency, resistance to external and internal environment disturbances etc.

Western concepts of financial stability are also based on resistance to external and internal environment factors of a company but the cornerstone of financial stability management is evaluation of its qualitative indicators. G.J. Schinasi [5] notes that financial stability evaluation may not be confined just to qualitative indicators. J. Pera [6] 
emphasizes that a stable company is a company continuing as a going concern which is able to resist internal and external disturbances showing no signs of loss of liquidity or solvency in the immediate future. It manifests itself as the company's operation in the circumstances of dynamic and stable balance with its internal environment. Western scientists describe financial stability in a fairly complete manner taking into consideration maintaining the balance in the corporate operations mentioned above.

Thus, the definitions considered above take into account the company internal state, its solvency, resource and capital management, external environment in which it operates, resistance to external factors but at the same time the considered definitions of financial stability fail to take into account efficient management of corporate resources which over the long term manifests itself in corporate profit and capital growth, hence, in enhancement of financial stability. In this context the author of this research gives his own definition of financial stability as the company's capability to resist internal and external threats, achieve its financial goals, maintain liquidity and solvency, ensure the optimal capital structure and performance efficiency in the circumstances of a turbulent environment [8]. This definition differs from interpretations of other researchers in that capital structure and performance efficiency are considered as factors of maintenance of financial stability of the company operating in a turbulent environment.

So, to sum up the above review of literature we can make several conclusions. First, the concept definition of financial stability is still controversial, but as the economic science develops it expands turning into a complex notion which describes a well-balanced corporate resources' and capital's utilization and a stable resistance to changes of external and internal environment. Second, expansion of the financial stability definition causes development of the tooling for its management and taking into consideration industry characteristics while conducting analytical procedures.

\section{Analysis of the Factors Which Influence Financial Stability in Economic Literature}

In the study of economic literature it should be noted that traditional analysis and management tools are not indicative of industry characteristics of company operations. However, when corporate management takes managerial decisions they pay great attention exactly to industry-related and external factors because they influence the company operations to a greater extent. Papers by Russian and foreign scientists show results of evaluation of industry-related factors' influence on operations of companies from various industry sectors. However, this influence is more confined to evaluation of internal factors and their impact on capital structure $[9 ; 10]$ or the corporate operating profitability $[11 ; 12]$.
M.A. Khalikov and M.A. Nikiforova proved that the degree of financial leverage has no response whatsoever to change of the debt to equity ratio, however, it is flexible in terms of the working capital profitability parameter. On this basis we can assert that for a diversified company in the circumstances of a highly variable market environment the problems of cost-effectiveness and financial stability enhancement are interrelated [9].

S.A. Mazeed, P. Sai Rani, R. Raveendranath, P. Divya, T. Sudharani [10] note that IT companies with a small capital and low operating expenses are highly-profitable, while IT companies with an average income may generate a moderate return at low costs of debt, so that their profitability will be greater. However, the share of debt in the capital structure plays an essential role and its increase results in profitability decline. In point of fact, the research proves antagonicity of the essence of financial stability and profitability. From the point of view of the capital structure a company independent from external financing cannot be profitable because use of equity capital for corporate operations does not promote its development.

Q. Huang, R. Kim [13] in their research studied the side effect of competition with import in the processing and sales industry on capital structure. The authors found out that a significant decrease of import rates in the consuming industry makes suppliers to choose a more conservative financial policy. Companies reduce the leverage when relations between the customer and supplier are more important for them. Summing up, Q. Huang, R. Kim noted that companies adjust their leverage mainly by issuing a greater number of shares. This research confirms that financial risks are reduced in relations with reliable and highly-reputable contractors.

B. Granville, R. Matousek and E. Sokolov [14] considered influence of uncertainty of economic policy on the factors of the capital structure. So they proved that large companies are less subjected to influence of economic uncertainty on the capital structure and to growth of financial risks due to their greater stability. In their opinion, government intervention in the Russian banking system results in the fact that companies which are strategically valuable for the government have privileges in debt financing unlike other Russian companies which makes them less resistant to financial risks.

Thi Thanh Thuy Vu, Thi Tu Oanh Le and Thi Huyen Trang Nguyen [11] in their paper analyzed the construction industry of Vietnam. The research proved existence of a strong positive relation between the share of fixed assets in the asset profile with return on assets and return on equity as well as that of the degree of financial leverage and return on equity. The degree of financial leverage and share of the long-term capital in the total amount of funding sources also have a negative impact on return on assets, i.e. in an economic recession with a low rate of the market development a high debt ratio may adversely affect profitability of total assets. This research reveals a contradiction in achieving financial stability and efficiency 
(performance) of the company operations. However, it has another consistent pattern: when financial risk reduces the return on assets grows. Consequently, by choosing the optimal capital structure and pursuing a moderate financial policy a company enhances the resource utilization efficiency.

The author of this paper made the same conclusion in early works [2] when assessing influence of financial stability indicators on return on assets using Russian construction companies as an example. This research also revealed a positive influence of the equity-assets ratio and financial stability on return on assets. In other words, when independence from external funding sources increases the resource utilization efficiency grows.

Finally, I would like to note that often industry characteristics manifest themselves in variability of external environment. So, it is important to take into consideration influence of external factors such as inflation, consumer purchasing power, loan interest rates etc. on company operations.

\section{Review of the Russian Construction Industry}

We chose the Russian construction industry as the observation object because it is characterized by a high turbulence, reforms in the housing financing. In this section we will consider the current status of the industry and influence of the introduced reform of transfer to project financing (implementation of escrow account) on the industry operation.

Construction is one of the most important types of Russian business activity. Nevertheless, there is a decrease in construction volume. It is caused by change of legislation, a serious tax burden and debt load, a high cost of construction supplies etc.

Since 2000 residential construction has been developing. Up to and including 2015 housing construction was growing (increment for this period amounted to approximately 50\%), however, since 2015 and till the present day construction volumes have been decreasing (Figure 1).

Figure 1. Amount of commissioning of residential buildings in the Russian Federation in 2000-2018, million sq. m.

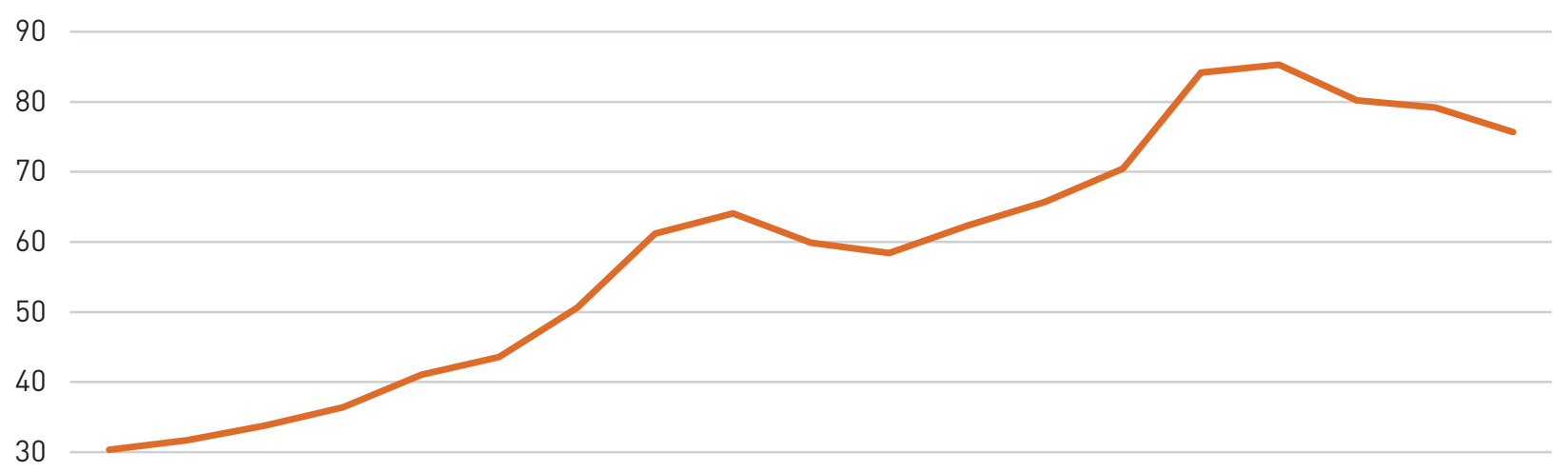

0

2000200120022003200420052006200720082009201020112012201320142015201620172018

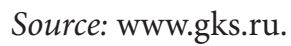

In accordance with Federal Law of 30.12.2004 No. 214-FZ (as amended on 27.06.2019) On Co-funding the Construction of Apartment Buildings and Other Real Estate Property and on Introducing Changes in Certain Legislative Acts of the Russian Federation since July 1, 2018 changes were introduced in the system of the construction industry financing which, in the opinion of the government of the Russian Federation and the Ministry of Construction, ensure protection of co-investors. On July 1, 2018 a prohibition on acceptance of co-investors' funds by construction companies entered into force. A new tool was introduced to attract the population's funds, that is an escrow account. The escrow account is opened with a commercial bank and is intended to freeze the co-investors' funds for the period of construction. After the construction company fulfills its obligations to the co-investors the money from the escrow account is transferred to the executor. Therein the construction is financed by commercial banks by means of project loans. This tool, on the one hand, helps to protect co-investors, on the other hand, - will elevate financial risks of construction companies.

Transfer from the target financing to project financing, on the one hand, will help to protect co-investors because the funds accrued on the escrow account may be transferred to the executor if two conditions are fulfilled: the building is commissioned and the right of ownership to at least one apartment is registered. This may have an adverse effect on construction companies because the construction permit will be issued only in case there is at list $10 \%$ of own funds in the total project cost of the apartment. Therein additional costs for the escrow account maintaining, increase of the volume and value of the debt capital will 
cause raise in the apartments' value in the primary market including the value at the stage of construction.

In the experts' opinion, a complete transfer of the construction industry to project financing will take approximately two or three years because the industry we study is a slow-response one, the projects take a long time to fulfill, besides, the companies which have obtained permits for construction before introducing new requirements operate on the basis of old regulations [15]. Among other things, the national project Residential Property and Urban Environment which provides for increase of the residential property commissioning, lowering of the mortgage rate and financial support of construction companies will help to mitigate the transfer to project financing

Thus, the society will experience influence of implementation of such tools as an escrow account in the construction industry operation in several years. Yet today we can assert that implementation of this measure will entail reduction in the number of construction companies, rise in prices in the primary market but at the same time solution of the problem of defrauded co-investors will enhance investors' confidence in construction companies.

\section{Experiment Description}

As noted above due to raising mainly debt financing the main factors which influence a construction company operations are external factors.

On the basis of official sources of the Federal State Statistics Service (https://rosstat.gov.ru/, https://www. fedstat.ru/) the factors which have impact on construction companies related to consumer purchasing power were identified because a high consumer purchasing power in particular causes increase in the volume of residential construction and improvement of its quality. Such factors are consumer price inflation, amount of investment in fixed capital per capita, gross regional product, mortgage rate, unemployment rate, net migration rate, average nominal salary, business confidence index etc.

At the first stage of the experiment a random sample of construction companies was performed. They were selected from construction companies of the Siberian Federal District of the Russian Federation. The sample comprises five construction companies from each constituent entity of the Siberian Federal District of the Russian Federation. Totally 50 companies were observed (Appendix 1).

At the second stage of the experiment financial stability of the construction companies from the sample was evaluated. We analyzed the dynamics of the capital structure factors such as equity-assets ratio, financial stability, financial leverage; liquidity and solvency indicators: current, absolute, quick liquidity ratios, total solvency ratio; return on equity and return on assets indicators. As a result of the analysis 18 companies are considered to be financially stable and 32 companies show signs of financial imbalance (Appendix 1). The main criteria for a company to get into the group of financially stable ones is compliance of the studied indicators with their recommended values.

At the third stage of the experiment we selected external factors which influence financial stability of construction companies of the Siberian Federal District of the Russian Federation (Table 1).

Table 1. Core statistical indicators for the Siberian Federal District in 2018

\begin{tabular}{|c|c|c|c|c|c|c|c|c|}
\hline 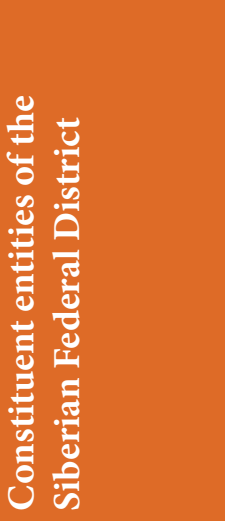 & 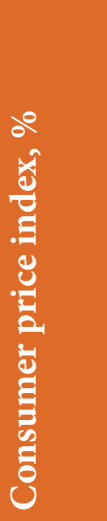 & 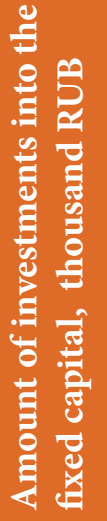 & 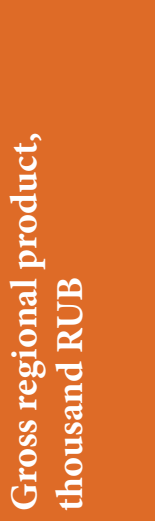 & 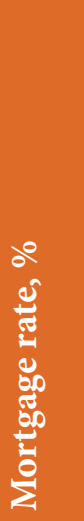 & 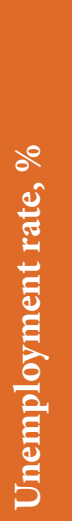 & 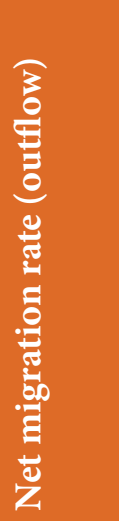 & 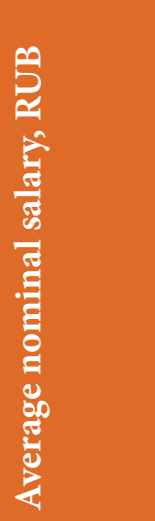 & 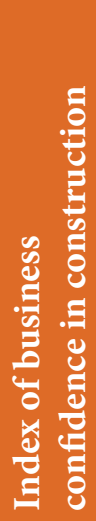 \\
\hline $\begin{array}{l}\text { Republic of } \\
\text { Altai }\end{array}$ & 102.6 & 56,657 & $231,464.2$ & 9.69 & 11 & -15.7 & $17,246.48$ & -48 \\
\hline Altai Territory & 104.36 & 44,409 & $234,885.9$ & 9.56 & 5.8 & -31.65 & $16,075.73$ & -27 \\
\hline Irkutsk Region & 105.37 & 95,676 & $580,152.8$ & 9.55 & 6.6 & -24.61 & $27,491.49$ & -20 \\
\hline $\begin{array}{l}\text { Kemerovo } \\
\text { Region }\end{array}$ & 104.7 & 59,768 & $462,495.1$ & $9 ., 54$ & 5.5 & -31.34 & $29,209.17$ & -20 \\
\hline
\end{tabular}




\begin{tabular}{|c|c|c|c|c|c|c|c|c|}
\hline 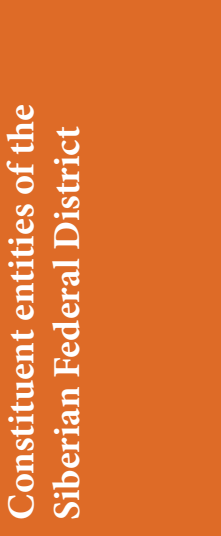 & 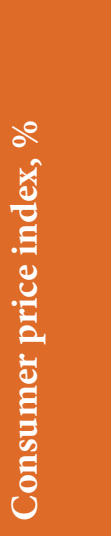 & 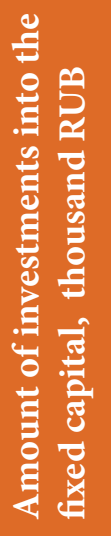 & 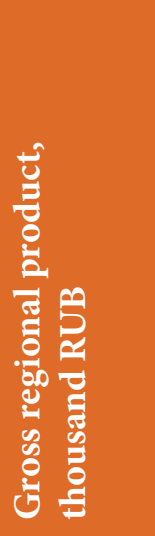 & 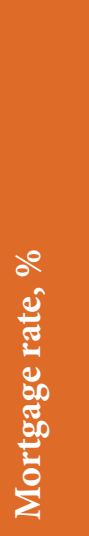 & 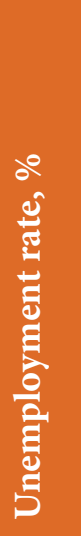 & 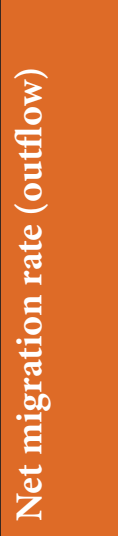 & 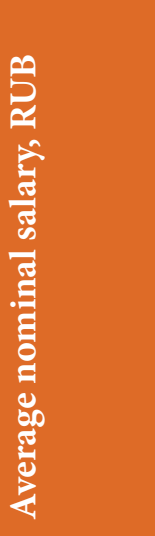 & 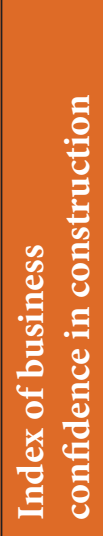 \\
\hline $\begin{array}{l}\text { Krasnoyarsk } \\
\text { Territory }\end{array}$ & 104.51 & 92,001 & $792,980.5$ & 9.57 & 4.5 & -0.97 & $40,813.26$ & -8 \\
\hline $\begin{array}{l}\text { Novosibirsk } \\
\text { Region }\end{array}$ & 103.68 & 64,826 & $448,658.8$ & 9.59 & 6.1 & 28.77 & $27,320.95$ & -23 \\
\hline Omsk Region & 104.13 & 59,648 & $349,165.7$ & 9.55 & 6.5 & -61.99 & $40,565.04$ & -16 \\
\hline Tomsk Region & 104.3 & 54,472 & $597,512.2$ & 9.5 & 5.5 & -6.15 & $24,022.61$ & -55 \\
\hline $\begin{array}{l}\text { Republic of } \\
\text { Tyva }\end{array}$ & 103.87 & 12,553 & $231,464.2$ & 9.54 & 12.4 & -30.33 & $18,906.28$ & -20 \\
\hline $\begin{array}{l}\text { Republic of } \\
\text { Khakassia }\end{array}$ & 105.47 & 45,217 & 438,326 & 9.54 & 6 & -16.69 & $37,617.08$ & -7 \\
\hline
\end{tabular}

A low variability of the consumer price index should be noted. In all constituent entities prices grow by $3-5 \%$. The mortgage rate in the constituent entities is almost the same, it is $9.5 \%$ in the whole district. The values of other indicators are notable for a high variability which is explained by existence of richer and less rich constituent entities in the Siberian Federal District. The value of the index of business confidence in construction in all constituent entities is negative which proves the complexity, uncertainty in operation of construction companies in the Siberian Federal District.

The fourth stage of the experiment consisted in choosing the method of study of external factors influence on financial stability of construction companies. We used the binary choice model on the basis of logit analysis (logit model). We singled out this method because the logit model allows to assess influence of factors on the dependent variable with two outcomes.

\section{Logit Model}

A lot of indicators characterizing financial stability with reference to which the conclusion of a stable or unstable financial position of construction companies was made determine the choice of the logit model.

For the binary variable the model is written as:

$\mathrm{y}_{\mathrm{i}}^{*}=\beta_{0}+\sum_{\mathrm{j}=1}^{\mathrm{k}} \beta_{\mathrm{i}} \mathrm{x}_{\mathrm{ij}}+\mathrm{u}_{\mathrm{i}}$, where $\mathrm{y}_{\mathrm{i}}^{*}$ - hidden (latent) variable,

$y_{i}^{*}=\left\{\begin{array}{l}1, y_{i}^{*}>0, \\ 0, y_{i}^{*}<0 .\end{array}\right.$

This is a probability model. In its turn the logit model is as follows:

$$
\mathrm{y}_{\mathrm{i}}^{*}=\ln \frac{\mathrm{P}_{\mathrm{i}}}{1-\mathrm{P}_{\mathrm{i}}}=\beta_{0}+\sum_{\mathrm{j}=1}^{\mathrm{k}} \beta_{\mathrm{i}} \mathrm{x}_{\mathrm{ij}}+\mathrm{u}_{\mathrm{i}},
$$

where $\mathrm{y}_{\mathrm{i}}^{*}-\operatorname{logit}$;

$\mathrm{P}_{\mathrm{i}}$ - probability of the dependent variable $\mathrm{Y}_{t}$ calculated on the basis of a logistic distribution:

$$
\begin{aligned}
& \frac{\mathrm{P}_{\mathrm{i}}}{1-\mathrm{P}_{\mathrm{i}}}=\mathrm{e}_{\mathrm{t}}^{\mathrm{y}^{*}}=\mathrm{e}^{\beta_{0}+\sum_{\mathrm{j}=1}^{\mathrm{k}} \beta_{\mathrm{i}} \mathrm{x}_{\mathrm{ij}}+\mathrm{u}_{\mathrm{i}}}, \\
& \hat{\mathrm{P}}_{\mathrm{i}}=\frac{1}{1+\mathrm{e}^{-\mathrm{y}_{\mathrm{t}}^{*}}}=\frac{1}{1+\mathrm{e}^{-\left(\beta_{0}+\sum_{\mathrm{j}=1}^{\mathrm{k}} \beta_{\mathrm{i}} \mathrm{x}_{\mathrm{ij}}+\mathrm{u}_{\mathrm{i}}\right)}} .
\end{aligned}
$$

Thus, applying the logit model we will determine with a better accuracy influence of external factors on financial stability of construction companies. 


\section{Results and Discussion}

Reviving the question of whether external factors influence financial stability of companies we would like to emphasize that the answer is obviously positive.

Table 2 shows a quantitative evaluation of external factors which influence financial stability of construction companies in the Siberian Federal District.
The data obtained after the logit analysis does not provide a basis for definite conclusions because due to a great number of factors included in the model their influence was "diluted". However, even now we can say that the greatest influence is exerted by the mortgage rate and consumer price index while the average nominal salary is the most significant factor. The numerous factors included in the model allow to exclude excessive variables. The study of excessive variables in the model gives the following results (Table 3).

Table 2. Influence of factors on financial stability of construction companies on the basis of logit model

\begin{tabular}{|c|c|c|c|c|}
\hline & Ratio & Standard error & $\mathbf{Z}$ & P value \\
\hline Const & -42.2347 & 760.330 & -0.05555 & 0.9557 \\
\hline Consumer price index & 0.405558 & 1.20692 & 0.3360 & 0.7369 \\
\hline $\begin{array}{l}\text { Amount of investment in fixed } \\
\text { capital per capita }\end{array}$ & $2.98469 \mathrm{e}-05$ & $3.42374 \mathrm{e}-05$ & 0.8718 & 0.3833 \\
\hline Gross regional product & $-1.41199 \mathrm{e}-07$ & $1.16236 \mathrm{e}-06$ & -0.1215 & 0.9033 \\
\hline Mortgage rate & 0.249076 & 67.5452 & 0.003688 & 0.9971 \\
\hline Unemployment rate & 0.0270021 & 0.267144 & 0.1011 & 0.9195 \\
\hline Net migration rate & -0.0191763 & 0.0323661 & -0.5925 & 0.5535 \\
\hline Average nominal salary & -0.000156994 & $7.06775 \mathrm{e}-05$ & -2.221 & $0.0263^{* *}$ \\
\hline Business confidence index & 0.0346476 & 0.108693 & 0.3188 & 0.7499 \\
\hline
\end{tabular}

Table 3. Influence of factors on financial stability of construction companies on the basis of logit model without taking into consideration excessive variables

\begin{tabular}{|c|c|c|c|c|}
\hline & Ratio & Standard error & $\mathbf{Z}$ & P value \\
\hline Const & -582.948 & 379.200 & -1.537 & \\
\hline Consumer price index & 1.27117 & 0.746052 & 1.704 & 0.1242 \\
\hline Mortgage rate & 47.3193 & 32.9403 & 1.437 & $0.0884^{*}$ \\
\hline Net migration rate & -0.0345858 & 0.0217027 & -1.594 & 0.1509 \\
\hline Business confidence index & -0.0394829 & 0.0502944 & -0.7850 & 0.1110 \\
\hline Average nominal salary & -0.000126946 & $5.88048 \mathrm{e}-05$ & -2.159 & $0.0309^{* *}$ \\
\hline
\end{tabular}

$\begin{array}{lclr}\text { Average dependent variable } & 0.360000 & \text { Standard deviation of the dependent variable } & 0.484873 \\ \text { McFadden R-squared } & 0.110983 & \text { Corrected R-squared } & -0.072666 \\ \text { Log. likelihood } & -29.04499 & \text { Akaike's criterion } & 70.08998 \\ \text { Schwarz criterion } & 81.56212 & \text { Hannan-Quinn criterion } & 74.45864\end{array}$

Number of 'correctly predicted cases' $=35(70.0 \%)$

$\mathrm{f}($ beta'x $)$ for the average variable of independent variables $=0.485$.

Likelihood ratio criterion: chi-square $(5)=7.25184[0.2026]$.

Predicted

$\begin{array}{cccc} & & 0 & 1 \\ \text { Observed } & 0 & 31 & 1 \\ & 1 & 14 & 4\end{array}$


Exclusion of excessive variables allows to make the conclusion that the strongest influence on financial stability of construction companies is exerted by the mortgage rate and consumer price growth index. It should be noted that rise in prices and increase of the mortgage rate will cause growth of financial stability. So increase in the price growth index by $1 \%$ will result in improvement of financial stability of construction companies by 1.27 points while increase of the mortgage rate by $1 \%$ will enhance financial stability of construction companies by 47.3 points. Besides growth of the migration rate and business confidence index will have a negative impact on financial stability of construction companies and will decrease it by 0.3 and 0.4 points relatively. Under otherwise equal conditions growth of the average nominal salary will adversely affect financial stability of construction companies and will reduce it by 0.0001 notwithstanding that salary growth is a factor improving the welfare of the community. In spite of such insignificant influence of the average nominal salary on financial stability of construction companies influence of this factor is the most significant one.

The test for errors of the first and second kind revealed that $70 \%$ of cases has been predicted correctly. This allows to take into consideration influence of the analyzed factors on financial stability of construction companies.

Thus, the likelihood of achieving financial stability under the influence of external factors will take the following form:

$$
\begin{aligned}
& \hat{\mathrm{P}}_{\mathrm{i}}=\frac{1}{1+\mathrm{e}^{-\mathrm{y}_{\mathrm{t}}^{*}}}= \\
& =\frac{1}{1+\mathrm{e}^{582,95-1,27 \beta_{1}-47,32 \beta_{2}+0,03 \beta_{3}+0,04 \beta_{4}+0,001 \beta_{5}+\mathrm{u}_{\mathrm{i}}}} .
\end{aligned}
$$

The experiment results may be interpreted in two ways. For example, a positive influence of the mortgage rate on financial stability of construction companies consists in the following: when demand for mortgage services is preserved financial stability actually improves but growth of the mortgage rate increases the financial load on the community and pushes down demand. Consequently, a fast growth of the mortgage rate may have a negative influence on income of construction companies and undermine financial stability.

In the dispute on the experiment outcome we would like to note that in order to support the construction industry on May 1, 2020 President of the Russian Federation offered to launch a special mortgage benefits programme with the rate of $6.5 \%$ aimed at assisting in purchase of the comfort-class residential property. The rate exceeding the abovementioned one will be subsidized from the Federal Treasury of the Russian Federation [16]. This measure will help to support the buyers and mortgage market but it will have a strong negative impact on financial stability of construction companies. This happens because co-investors' funds are not construction companies' income or proprietary funds, they are rather used as target financing. After transfer to the project financing the co-investors' funds will be available to a construction company only after commissioning of a residential building. Thus, the reform of the construction industry financing will have a negative impact on companies' operations because expansion of demand to mortgage loans will prompt construction companies to use banks' loan assets. The cost of such assets is much higher than the value of investment money used according to a traditional pattern of a co-investment agreement.

Generally we would like to note that taking into consideration influence of external factors on financial stability facilitates optimal resource management. If an external factor changes construction companies may adjust the financial strategy and manage resources in such a way which minimizes their influence on the company operations.

\section{Conclusion}

Financial stability is one of the main factors of corporate development. A stable financial position helps a company to survive troubled times increasing its income and capital and over the long term is a guarantee of a commercial company's efficient operation.

The conducted research revealed that the concept definition of financial stability is a complex notion describing a well-balanced utilization of corporate resources and capital and a firm resistance to changes of the external and internal environment. Expansion of the concept definition of corporate financial stability facilitates development of the tools for its management and taking into consideration industry characteristics when analytical procedures are carried out.

Resistance to external environment disturbances and revealing the influence of external factors is of most importance in the financial stability management. The research determined that construction companies of the Siberian Federal District are under the influence of the mortgage rate and consumer price index while the most significant influence on financial stability is exerted by the nominal average salary. If these factors are taken into consideration for construction companies' resource planning and management the companies will be able to resist more firmly influence of the external environment and to enhance financial stability.

\section{References}

1. Kovalev V.V. Financial management: theory and practice. Moscow: TK Velbi; Prospekt; 2008. 1024 p. (In Russ.).

2. Boronenkova S.A., Mel'nik M.V. Comprehensive financial analysis in enterprise management. Moscow: FORUM; INFRA-M; 2017. 335 p. (In Russ.).

3. Savitskaya G.V. Comprehensive analysis of the economic activities of the enterprise. Moscow: INFRA-M; 2017. 608 p. (In Russ.). 
4. Vladimirova T.A., Sokolova T.V. Financial stability of the organization: Essence, content, approaches to assessment. Sibirskaya finansovaya shkola = Siberian Financial School. 2017;(5):44-47. (In Russ.).

5. Schinasi G.J. Defining financial stability. IMF Working Paper. 2004;(187). URL: https://www.imf. org/external/pubs/ft/wp/2004/wp04187.pdf

6. Pera J. An enterprise's financial stability and its sustainable growth. A risk-based perspective. Przedsiębiorczość Międzynarodowa = International Entrepreneuship. 2017;3(2):49-62. DOI: 10.15678/ PM.2017.0302.04

7. Fayantzeva E.Yu. The risk of reducing the financial stability of the enterprise in modern conditions. Effektivnoe antikrizisnoe upravlenie = Effective Crisis Management. 2014;(3):84-89. (In Russ.).

8. Vlasenko M.A., Baranova I.V. Managing financial stability in a turbulent environment. In: Economic and social development. Proc. $47^{\text {th }}$ Int. sci. conf. on economic and social development (Prague, 14-15 Nov. 2019). Varazdin: Varazdin Development and Entrepreneurship Agency; 2019:401-409. URL: https://www.esd-conference.com/upload/book of proceedings/Book of Proceedings esdPrague2019 Online.pdf

9. Khalikov M.A., Nikiforova M.A. Economic efficiency and risk of the structure of the working capital of the enterprise. Fundamental'nye issledovaniya $=$ Fundamental Research. 2018;(6):222-228. (In Russ.).

10. Mazeed S.A., Rani P.S., Raveendranath R., Divya P., Sudharani T. Effectiveness of capital structure on profitability - IT companies perspective. International Journal of Innovative Technology and Exploring Engineering. 2019;9(1):726-728. DOI: 10.35940/ijitee. A4204.119119

11. Vu T., Le T., Nguyen T. The impact of capital structure on the performance of construction companies: A study from Vietnam stock exchanges. Accounting. 2020;6(2):169-176. DOI: 10.5267/j. ac.2019.10.006

12. Vlasenko M.A., Baranova I.V. Improving the tools for financial analysis of construction organizations: An industry aspect. Vestnik Tomskogo gosudarstvennogo universiteta. Ekonomika = Tomsk State University. Journal of Economics. 2019;(45):174-185. (In Russ.). DOI: $10.17223 / 19988648 / 45 / 12$

13. Huang Q., Kim R. Capital structure decisions along the supply chain: Evidence from import competition. Journal of International Business Studies. 2019;50(6):873-894. DOI: 10.1057/s41267-01900225-9
14. Granville B., Matousek R., Sokolov E. The impact of economic policy uncertainty on capital structure: Evidence from Russia. Korporativnye finansy = Journal of Corporate Finance Research. 2019;13(4):719. DOI: $10.17323 /$ j.jcfr.2073-0438.13.4.2019.7-19

15. Will a self-regulatory organization protect builders: On the consequences of the shared construction reform for the Novosibirsk construction market and the role of SROs. NGS.ru. Sept. 11, 2018. URL: https://news.ngs.ru/articles/65369291/ (accessed on 14.09.2019). (In Russ.).

16. Putin spoke about the new program of preferential mortgages. RIA Novosti. Apr. 16, 2020. URL: https:// realty.ria.ru/20200416/1570157234.html?utm_ source $=$ yxnews\&utm_medium $=$ desktop\&utm_ referrer=https\%3A\%2F\%2Fyandex.ru\%2Fnews (accessed on 17.04.2020). (In Russ.).

17. Thabhiranrak T., Jermsittiparsert K. Towards sustainable functioning of organization: Women empowernment and corporate management culture. Journal of Security and Sustainability Issues. 2019;9(1):321-332. DOI: 10.9770/jssi.2019.9.1(24)

18. Vlasenko M.A., Baranova I.V. Managing financial stability in a turbulent environment. In: Economic and social development. Proc. $47^{\text {th }}$ Int. sci. conf. on economic and social development (Prague, 14-15 Nov. 2019). Varazdin: Varazdin Development and Entrepreneurship Agency; 2019:401-409. URL: https://www.esd-conference.com/upload/book of proceedings/Book of Proceedings esdPrague2019 Online.pdf

19. An Z., Li D., Yu J. Earnings management, capital structure, and the role of institutional environments. Journal of Banking \& Finance. 2016;68:131-152. DOI: 10.1016/j.jbankfin.2016.02.007

20. The Central Bank thought about cutting the key rate. RIA Novosti. Apr. 17, 2020. URL: https://ria.ru/20200417/1570176547.html?utm_ source=yxnews\&utm_medium=desktop\&utm_ referrer=https $\% 3 \mathrm{~A} \% 2 \mathrm{~F} \% 2 \mathrm{Fyandex.ru} \% 2$ Fnews (accessed on 10.04.2020). (In Russ.). 


\section{Appendix 1}

Evaluation of the ratios of financial stability and return on assets of construction companies in the Siberian Federal District of the Russian Federation for 2017-2018

\begin{tabular}{|c|c|c|c|c|c|c|c|c|}
\hline Short name & $\begin{array}{l}\text { 2017, debt to equity } \\
\text { ratio, } \%\end{array}$ & $\begin{array}{l}2018, \text { debt to equity } \\
\text { ratio, \% }\end{array}$ & $\begin{array}{l}2017 \text {, net debt to capi- } \\
\text { tal ratio, } \%\end{array}$ & $\begin{array}{l}2018, \text { net debt to capi- } \\
\text { tal ratio, } \%\end{array}$ & 2017 , equity ratio, $\%$ & 2018 , equity ratio, $\%$ & $\begin{array}{l}\text { 2017, return on assets } \\
\text { (ROA), \% }\end{array}$ & $\begin{array}{l}\text { 2018, return on assets } \\
(\mathrm{ROA}), \%\end{array}$ \\
\hline ACTIVSTROYINVEST LLC & $1,262.89$ & $2,273.01$ & 9.98 & 7.46 & 7.34 & 4.21 & 0.34 & -4.59 \\
\hline ZHILREMMONTAZH LLC & 242.28 & 175.94 & -1.90 & -0.72 & 29.22 & 36.24 & -24.23 & 18.40 \\
\hline $\begin{array}{l}\text { CONSTRUCTION COMPANY } \\
\text { VOSTOK LLC }\end{array}$ & $1,136.31$ & 837.54 & 0.42 & 0.56 & 8.09 & 10,67 & 1.42 & -1.45 \\
\hline $\begin{array}{l}\text { SIBERIAN CONSTRUCTION COM- } \\
\text { PANY ETALONPROM }\end{array}$ & 960.28 & -186.24 & 34.93 & -0.99 & 9.43 & -115.95 & 8.44 & -63.43 \\
\hline CITYSTROY LLC & 10.84 & 0.70 & -2.00 & -0.17 & 90.22 & 99.31 & 10.91 & 5.14 \\
\hline SIBTRANSSTROY LLC & 16.83 & 13.61 & -0.61 & -0.01 & 85.59 & 88.02 & 10.03 & 0.54 \\
\hline TGSK INVEST LLC & $-16,196.78$ & $-14,986.35$ & -84.16 & -290.27 & -0.62 & -0.6 & -0.02 & -0.18 \\
\hline ISC CONSULTINGSTROYINVEST & $2,327.34$ & $1,277.34$ & $1,357.75$ & 237.13 & 4.12 & 7.26 & 3.39 & 2.64 \\
\hline RSK LLC & $4,011.59$ & $4,011.59$ & 0.00 & & 2.43 & 2.43 & -1.53 & \\
\hline SSP LLC & $-5,438.10$ & $-34,471.70$ & 557.36 & $-13,481.13$ & -1.87 & -0.29 & 0.94 & -0.13 \\
\hline STROYMODUL LLC & 57.37 & 55.32 & -6.41 & -6.14 & 63.55 & 64.38 & 35.41 & 32.24 \\
\hline ALIANS-SYSTEMY LLC & 323.81 & 500.00 & 1.90 & 152.63 & 23.60 & 16.67 & -2.62 & -6.44 \\
\hline ISS LLC & $2,584.28$ & $1,182.14$ & 87.25 & 237.75 & 3.73 & 7.80 & 1.30 & 1.73 \\
\hline NORMA-LUX LLC & 466.38 & -156.30 & -310.83 & 6.20 & 17.66 & -177.62 & 7.4 & -105.18 \\
\hline $\begin{array}{l}\text { CONSTRUCTION COMPANY } \\
\text { OMSK-TRACE LLC }\end{array}$ & $1,341.72$ & $1,805.33$ & 493.08 & 451.23 & 6.94 & 5.25 & 0.57 & 0.19 \\
\hline $\begin{array}{l}\text { YUZHSTROY-GRUPP LLC YUS- } \\
\text { GRUPP LLC }\end{array}$ & 694.53 & 428.51 & -85.81 & -63.65 & 12.59 & 18.92 & 8.67 & 12.60 \\
\hline SIBPROMGAZ LLC & 699.22 & 508.49 & -25.34 & -56.33 & 12.51 & 16.43 & 9.59 & 6.63 \\
\hline $\begin{array}{l}\text { STROITELNAYA COMPANIYA RAI } \\
\text { LLC }\end{array}$ & 69.55 & 36.29 & 15.63 & 11.30 & 58.98 & 73.37 & 71.18 & 71.08 \\
\hline SIBIRSPETSMONTAZH LLC & 4.51 & 1.97 & -16.77 & -47.82 & 95.68 & 98.07 & 1.20 & 10.56 \\
\hline KKhM-KUZNETSK LLC & 862.20 & 790.74 & -1.82 & 0.86 & 10.39 & 11.23 & 0.19 & 0.21 \\
\hline YULAN LLC & $3,979.07$ & $1,817.65$ & 0.00 & -243.70 & 2.45 & 5.21 & 0.90 & 1.14 \\
\hline RSK EUROPA LLC & 87.36 & 136.97 & -16.63 & 10.96 & 53.37 & 42.20 & 28.80 & 11.42 \\
\hline TVORETS LLC & 176.63 & 187.07 & 39.30 & 35.25 & 36.15 & 34.83 & 0.56 & 0.11 \\
\hline AGRIK-KS LLC & 52.02 & 26.21 & -7.50 & -2.38 & 65.78 & 79.24 & 25.78 & 3.63 \\
\hline PSM LLC & -672.77 & $-1,185.50$ & 2.80 & -3.88 & -17.46 & -9.21 & -8.12 & 9.30 \\
\hline $\begin{array}{l}\text { CAPITAL CONSTRUCTION MAN- } \\
\text { AGEMENT ZHILSTROY LLC }\end{array}$ & $-10,002.04$ & $-76,625.81$ & $-1,784.08$ & $-11,299.30$ & -1.01 & -0.13 & -2.80 & 0.78 \\
\hline
\end{tabular}




\begin{tabular}{|c|c|c|c|c|c|c|c|c|}
\hline Short name & $\begin{array}{l}2017 \text {, debt to equity } \\
\text { ratio, \% }\end{array}$ & $\begin{array}{l}2018 \text {, debt to equity } \\
\text { ratio, \% }\end{array}$ & $\begin{array}{l}\text { 2017, net debt to capi- } \\
\text { tal ratio, } \%\end{array}$ & $\begin{array}{l}\text { 2018, net debt to capi- } \\
\text { tal ratio, } \%\end{array}$ & 2017 , equity ratio, $\%$ & 2018 , equity ratio, $\%$ & $\begin{array}{l}\text { 2017, return on assets } \\
\text { (ROA), \% }\end{array}$ & $\begin{array}{l}\text { 2018, return on assets } \\
\text { (ROA), \% }\end{array}$ \\
\hline KHAKASGRAZHDANSTROY LLC & 517.70 & 417.03 & 208.37 & 187.03 & 17.05 & 19.34 & 2.31 & 3.07 \\
\hline REGIONSTROY LLC & 275.89 & -527.69 & -31.18 & -80.43 & 26.60 & -23.38 & 19.26 & 10.02 \\
\hline SKADI LLC & 128.72 & 118.03 & 76.24 & -0.21 & 76.30 & 83.73 & -0.61 & 0.40 \\
\hline $\begin{array}{l}\text { MUNICIPAL UNITARY } \\
\text { ENTERPRISE ATB }\end{array}$ & 528.05 & 249.77 & -1.43 & -87.73 & 15.92 & 28.59 & 46.52 & 13.56 \\
\hline TAVAL LLC & $2,377.33$ & 410.83 & -11.92 & -409.23 & 4.04 & 19.58 & 0.64 & 10.30 \\
\hline $\begin{array}{l}\text { CONSTRUCTION COMPANY GO- } \\
\text { ROD LLC }\end{array}$ & 112.65 & 32.14 & -3.95 & -48.49 & 47.03 & 75.68 & 7.98 & 36.68 \\
\hline $\begin{array}{l}\text { CONSTRUCTION COMPANY SIB- } \\
\text { PROMSTROY LLC }\end{array}$ & $1,197,024.24$ & $-4,667.49$ & $139,331.82$ & -760.57 & 0.01 & -2.19 & 0.01 & -2.46 \\
\hline MASTER LLC & 1.65 & 6.30 & -39.46 & -27.35 & 98.37 & 94.07 & 5.32 & 72.87 \\
\hline SIBSTROYREGION LLC & 1.58 & 820.17 & -93.22 & -91.60 & 98.45 & 10.87 & -8.13 & -51.10 \\
\hline SSK LLC & 19.37 & 0.99 & -23.95 & -0.63 & 83.77 & 99.02 & 21.99 & -8.63 \\
\hline $\begin{array}{l}\text { PRODUCTION COMPANY } \\
\text { AVANTE LLC }\end{array}$ & $4,786.57$ & $-18,646.15$ & $3,534.68$ & $-13,895.13$ & 2.05 & -0.54 & -3.05 & -2.59 \\
\hline $\begin{array}{l}\text { PRODUCTION COMPANY PROM- } \\
\text { STROY LLC }\end{array}$ & 94.31 & 190.79 & 53.61 & 141.84 & 51.47 & 34.39 & 8.47 & 1.88 \\
\hline SIB-SERVICE LLC & 259.98 & 361.66 & -20.04 & 20.21 & 27.78 & 21.66 & 7.50 & 0.37 \\
\hline STROYENERGOMONTAZH LLC & $4,269.89$ & $3,829.81$ & $-2,092.30$ & $1,324.11$ & 2.29 & 2.54 & 3.51 & 0.77 \\
\hline SPETSSTROYINVEST LLC & 5.96 & 3.41 & -89.20 & -13.94 & 94.37 & 96.70 & 27.06 & 3.56 \\
\hline SIBSPETSSTROY LLC & -424.28 & 50.49 & -237.74 & -12.53 & -30.84 & 66.50 & -78.72 & 95.31 \\
\hline TECHNOSIBBAIKAL & 432.83 & $121,046.15$ & 23.12 & $-13,138.46$ & 18.77 & 0.08 & 2.45 & -32.34 \\
\hline CHKHOLSAN LLC & 29.82 & 135.74 & -82.85 & 16.94 & 77.03 & 42.42 & 26.01 & -14.53 \\
\hline SKIF LLC & 147.60 & 63.41 & -1.42 & $-24 ., 98$ & 40.39 & 61.20 & 0.60 & 1.13 \\
\hline SIBINVESTSTROY & -241.50 & -175.08 & 0.00 & & -70.67 & -133.20 & -22.64 & -14.32 \\
\hline YUNOST LLC & 127.18 & 82.02 & -130.69 & -51.70 & 44.02 & 54.94 & 45.48 & 12.67 \\
\hline OLCHEY LLC & 629.55 & 330.65 & 23.02 & -254.80 & 13.71 & 23.22 & 14.12 & 10.47 \\
\hline SUUGU LLC & 45.97 & 40.41 & -5.28 & -6.40 & 68.51 & 71.22 & -3.97 & -1.62 \\
\hline ULU LLC & 227.84 & 187.89 & 203.75 & 176.68 & 30.50 & 34.74 & -136.66 & 5.44 \\
\hline
\end{tabular}

